\title{
НАВЧАЛЬНО-БІОЛОГІЧНИЙ МУЗЕЙ ІМЕНІ І. І. ЯРЕМЕНКА
}

Л. Я. Федонюк

\author{
ДВНЗ “Тернопільський державний медичний університет \\ імені І. Я. Горбачевського МОЗ Украйни”
}

\section{I. YAREMENKO EDUCATIONAL AND BIOLOGICAL MUSEUM}

\author{
L. Ya. Fedonyuk \\ SHEI "Ternopil State Medical University by I. Ya. Horbachevsky of \\ MPH of Ukraine"
}

\begin{abstract}
Серед великої різноманітності оточуючої нас живої природи одне з перших місць займають натуральні об’єкти та їх зображення. 3 огляду на це, певне місце в навчально-виховному процесі займають природничі та навчально-біологічні музеї. Вони мають актуальне значення при вивченні будови багатоклітинних організмів, ролі людини у зміні природних екосистем, дають можливість формувати систему знань про закони природи, є базою для дослідження основ паразитизму та паразитарних інвазій у людини.

Among a variety of surrounding nature natural objects and their images occupy one of the leading places. In this respect natural and biological educational museums have a certain place in the educational process. They are of a topical importance while learning the structure of multicellular organisms and the human role in changing natural ecosystems. They afford an opportunity to form the system of knowledge concerning the laws of nature and are the foundation to study the bases of parasitism and parasitic invasions in the man.
\end{abstract}

Вступ. У стінах кафедри медичної біології, що розташована у корпусі інституту медико-біологічних проблем в одному з наймальовничіших місць м. Тернополя, знаходиться її гордість - навчально-біологічний музей, засновником якого у 1957 році став перший завідувач кафедри біології Тернопільського медичного інституту кандидат біологічних наук, доцент Іван Іванович Яременко [1].

Основна частина. У короткому довіднику про навчальний музей, написаному ще у 1974 році, Іван Іванович зазначав: "Виходячи з вчення I. П. Павлова про взаємозв' язок першої і другої сигнальної систем, дидактика вищої школи, серед ряду інших засобів, обгрунтувала важливу роль свідомого засвоєння знань, в тому числі студентами вузів. Серед різноманітності наочностей одне з перших місць повинні зайняти натуральні об'єкти і їх зображення, які створюють найповніше уявлення змісту оточуючої нас живої природи. 3 огляду на це, певне місце в навчально-виховному процесі повинні зайняти музеї. Це особливо має актуальне значення при вивченні однієї 3 фундаментальних дисциплін -біології” [2].

При оформленні музею особливу увагу Іван Іванович надав показу єдності організмів і середовища,

(C) Л. Я. Федонюк походження живого з неживої матерії, великої різноманітності рослинного та тваринного світу, сучасних принципів побудови організмів, процесів розмноження та розвитку, питань спадковості та мінливості, надавши музею біологічного спрямування.

У 1967 році відбулось урочисте відкриття музею, що збіглося з 10-ю річницею заснування Тернопільського медичного інституту.

На сьогодні навчально-біологічний музей займає площу $44 \mathrm{~m}^{2}$, він нараховує 2155 експонатів, серед яких: 345 опудал тварин, 263 вологих макропрепарати, 64 скелети тварин, 5 колекцій представників класу Комахи, що налічує понад 500 особин, близько 260 муляжів, схем і моделей.

Більшість опудал тварин - представників рядів хижаки, парнокопитні, гризуни, голубоподібні та куроподібні виготовлено особисто Іваном Івановичем Яременком, оскільки сфера його наукових інтересів і досліджень стосувалась біологічних і екологічних аспектів фауни західних областей України.

У 2012-2013 роках колективом кафедри медичної біології за особистої підтримки ректора ДВНЗ “Тернопільський державний медичний університет імені I. Я. Горбачевського МОЗ України" чл.-кор. НАМН України, професора Л. Я. Ковальчука було проведе- 
но велику роботу щодо реорганізації та реставрації навчально-біологічного музею.

Основною метою реорганізації стала спільна ідея запобігання явищу, коли музеї перетворюються на набори монотонних несистематизованих експонатів, фактів і явищ. Генеральна ціль одночасного роз'єднання та об'єднання між собою біологічного, природоохоронного, екологічного, еволюційного та медичного напрямків дали можливість створити повне уявлення про оточуюче нас середовище та надати медико-біологічного змісту живій природі.

У навчально-біологічному музеї сформовано дві секції:

1. "Еволюція землі, біосфери та людини";

2. “Жива природа - багаторівнева система землі”.

Кожна секція включає ряд експозицій. Зокрема, секція “Еволюція землі, біосфери та людини” включає три експозиції: 1.1. "Хронологія еволюції живої природи”, 1.2. “Шлях еволюціїлюдини за Дарвіном”, 1.3. “Жива природа в геологічному минулому”.

Секція “Жива природа - багаторівнева система землі”" включає 8 експозицій: 2.1. "Видатний біолог і засновник кафедри - I. І. Яременко", 2.2. "Царство тварини в імперії Еукаріот”, 2.3. “Отруйні тварини”, 2.4. "Медико-біологічні аспекти паразитизму", 2.5. “Представники класу Комахи", 2.6. "Поняття екосистеми в сучасній екології”, 2.7. “Червонокнижні рослини та тварини Тернопільщини”, 2.8. "Природнозаповідні території Тернопільщини".

Секція "Видатний біолог і засновник кафедри I. I. Яременко" присвячена життєвому шляху, науковим дослідженням і трудовій діяльності першого завідувача кафедри біології - Івана Івановича Яременка.

Експозиція "Царство тварини в імперії Еукаріот" займає центральну частину музею. Під неї відведено 18 скляних вітрин, в яких продемонстровано величезне розмаїття безхребетних і хребетних тварин. Найбільшим таксонам відведені окремі вітрини, де розташована детальна інформація щодо систематики, морфології, екології та життєвого циклу тварин.

Огляд даної експозиції розпочинається із представників типу Губки. У вітринах можна ознайомитись із будовою Кишковопорожнинних на прикладі прісноводного поліпа гідри, а також побачити різноманітність коралів, скелети яких відрізняються не лише за формою, а й за кольором - білі, червоні, блакитні.

Наступна вітрина присвячена представникам типу Молюски. В ній розташовані експонати тварин класів: Черевоногі, Двостулкові та Головоногі.
Вітрина, присвячена представникам типу Кільчасті черви, містить детальну характеристику класів: Малощетинкові та Багатощетинкові. Окремо представлено вологі препарати п'явок та інформацію щодо їх медичного застосування.

В одній із наступних вітрин розташовані морські зірки та морські ̈̈жаки, що належать до типу Голкошкірі.

Ряд вітрин, присвячений представникам типу Членистоногі, демонструють експонати тварин класів: Ракоподібні, Павукоподібні та Комахи.

Внутрішню будову ракоподібних можна вивчати на прикладі будови річкового рака, яка представлена на вологих макропрепаратах і навчальних наборах.

Привертають на себе увагу бджолині стільники та осине гніздо, а також колекція яскравих метеликів.

Продовженням експозиції є вітрини представників надкласу Риби. Із їх зовнішньою та внутрішньою будовою можна ознайомитись на вологих препаратах, скелетах, схемах і муляжах будови внутрішніх органів. Яскравими експонатами даних вітрин $€$ опудала акули-катран і ската-райя.

Наступні вітрини знайомлять нас із представниками класу Земноводні.

Різноманітність тварин класу Плазуни та особливості їx середовища існування можна побачити на наступній вітрині, де розташовані опудало варана сірого, вологі макропрепарати триголового пітона, вужа звичайного, амурського, степового та смугастого полозів, веретільниці ламкої.

Внутрішню будову рептилій можна вивчати на вологих препаратах кавказької ящірки. В експозиції наявні скелет і вологі препарати черепах.

Однією з найбільш чисельних колекцій тварин $є$ вітрини, в яких представлений клас Птахи, що проживають у різних географічних зонах України. Звертає на себе увагу вітрина із пташиними яйцями, від найбільшого - страусиного - до одного із найменших - перепелиного. В окремій вітрині розташовані вологі макропрепарати, на яких можна вивчати внутрішню будову птахів.

На наступній вітрині можна ознайомитись із прикладами гомологічних та аналогічних органів серед представників типу Хордові.

Завершенням експозиції є вітрини, в яких представлені тварини класу Ссавці. Особливості їх будови можна вивчати за допомогою чисельних вологих макропрепаратів, скелетів і навчальних наборів.

Історія експозиції “Отруйні тварини” сягає своїм корінням глибоко в історію кафедри, адже I. I. Яре- 
менко значну увагу приділяв вивченню отруйних тварин. Саме таким істотам присвячена одна із його монографій “Отруйні тварини”. Експозиція представлена вологими препаратами, опудалами отруйних тварин та інформаційними стендами, на яких розміщені матеріали щодо загальної характеристики отруйних тварин, їх класифікації, способу існування. В окремій вітрині розташована інформація, в якій висвітлено клінічну картину токсичної дії отрути, правила надання першої допомоги при укусах отруйних тварин, а також висвітлено особливості зміїної отрути та ії застосування в медицині.

Експозиція "Медико-біологічні аспекти паразитизму" згрупована за принципом взаємодії паразита та хазяїна на рівні особин, вона наглядно демонструє природно-осередковий характер паразитарних захворювань, надаючи чітку уяву про взаємозв' язок способу життя тварин із проявами паразитарних захворювань, цим самим формуючи клінічне мислення у майбутніх фахівців медицини.

Експозиція оформлена на стіні площею 30 м². На ній у спеціальних контейнерах, із урахуванням біологічної систематики, послідовно розташовані опудала тварин класів: Ракоподібні, Хрящові та Кісткові риби, Птахи, Гризуни, Зайцеподібні, Комахоїдні, Хижі, Парнокопитні та Примати. Під контейнерами з опудалами тварин, на спеціальних стендах, які стоять на вітринах центральної експозиції, розташована інформація по 13 захворюваннях, збудниками, переносниками або хазяями яких є тварини, розташовані на стіні. По 7 інфекційних і 6 інвазійних захворюваннях зазначено та проілюстровано систематичне положення, морфологію, цикл розвитку збудника, шляхи зараження, клінічну картину, методи лабораторної діагностики та профілактики захворювання.

Експозиція “Представники класу Комахи” створена на основі колекції, зібраної завідувачем кафедри нормальної фізіології доктором медичних наук, професором Костянтином Васильовичем Ковановим і подарованої ним навчально-біологічному музею у 1992 році. Впродовж 2013 року проводилась ідентифікація, систематизація та підпис відповідно до сучасних вимог 204 експонатів. Колекцію розташували та оформили у спеціально виготовлених контейнерах, що забезпечуватимуть тривале зберігання комах. 117 представників ряду Лускокрилі згруповано за напрямками “Мінливість" та "Видова різноманітність метеликів".

Експозиція "Поняття екосистеми в сучасній екології” представлена взірцями прісноводних і назем- них екосистем за схемою: продуценти, консументи I, II та III порядку. Експозиція побудовано за рівневим типом із метою візуалізації ланцюгів живлення та правил екологічної піраміди.

В експозиції “Червонокнижні рослини та тварини Тернопільщини”, яка займає 2 скляні вітрини, представлені гербарні зразки 29 рідкісних видів рослин, зібраних в околицях Тернополя, поблизу міст Кременець та Гусятин.

У ній також представлені зникаючі види тварин Тернопільщини, опудала яких власноруч виготовлені працівниками кафедри під керівництвом I. І. Яременка. Усі експонати підписані відповідно до сучасних систематичних уявлень, на стендах подано коротку інформацію про екологічні та біологічні особливості виду, причини скорочення чисельності та фактори, що сприяють їх відновленню.

Окрасою експозиції є гербарні взірці зникаючих видів рослин Тернопільської області, що подаровані музею працівниками кафедри ботаніки Тернопільського національного педагогічного університету імені Володимира Гнатюка у 2013 році.

Вагомою цінністю експозиції є Червона книга України - основний документ, в якому узагальнено матеріали про сучасний стан рідкісних і таких, що знаходяться під загрозою зникнення, видів тварин і рослин. На підставі цього природоохоронного документа розробляються наукові та практичні заходи, спрямовані на охорону природи та ії раціональне використання. Примірник “Червона книга України (рослинний світ)” та “Червона книга України (тваринний світ)" подаровані музею авторами даного видання працівниками Інституту зоології Національної академії наук України у 2012 році.

У рамках експозиції “Природно-заповідні території Тернопільщини" представлена регіональна карта-схема територій та об'єктів екологічної мережі Тернопільської області, що мають рекреаційну цінність. Зображені як існуючі природно-заповідні території, так i перспективні для заповідання об'єкти.

На одному із підвіконників музею оформлена стилізована виставка птахів - представників фауни Західного регіону України.

У навчально-біологічному музеї систематично проходять тематичні екскурсії для школярів, відбуваються засідання студентського наукового гуртка, читаються міні-лекції та проводяться зустрічі з ветеранами кафедри медичної біології.

На даний час навчально-біологічний музей має багатогранне значення: навчальне, наукове та вихов- 
не. Навчальне: експонати музею відображають тематичні розділи програми з дисципліни, за допомогою яких студенти спостерігають взаємозв' язок рослинного та тваринного світу, організмів між собою та навколишнім середовищем, формують уявлення про будову багатоклітинних організмів, а також вивчають роль людини у зміні природних екосистем. Наукове: експозиції секцій музею цінні тим, що формують систему знань про закони природи, вони $\epsilon$ базою для дослідження основ паразитизму та паразитарних інвазій у людини. Виховне: музей формує

\section{Література}

1. Майбутнс твориться сьогодні (2007-2012)/[М. А. Андрейчин, С. М. Андрейчин, Л. С. Бабінець та ін.]. - Тернопіль : ТДМУ, 2012.-428 c. гуманне, дбайливе та бережливе ставлення до природи рідного краю, вміння естетично ставитись до всього живого, він відіграє важливу роль у формуванні екологічної свідомості студентів.

Висновок. Навчально-біологічний музей $\epsilon$ експозиційним проектом і залишається освітнім ресурсом кафедри. У ньому відображено не лише історію створення музею природи, але й історію кафедри, історію інституту, академії, університету. Музей завжди був та залишається гордістю за людей, які заклали його фундамент.

2. Педагог і дослідник біологічного циклу / [уклад. Л. Я. Федонюк та ін.]. - Тернопіль : ТДМУ, 2013.-20 c.

Отримано 22.04.14 